\title{
THE POSIBILITY IMPACTS OF FREE FLOW OF GOODS IN ASEAN ECONOMIC COMMUNITY ON INDONESIA ANTI DUMPING ACTIONS
}

\author{
Abdurrahman Alfaqiih* \\ Business Law Department, Faculty of Law Islamic University of Indonesia, Yogyakarta \\ Jalan Tamansiswa No.158, Yogyakarta, D.I. Yogyakarta PO BOX 1133
}

\begin{abstract}
One of the top aims of ASEAN Economic Community (AEC) establishment is to create trade that is free from any kind of barriers. Nonetheless, not every country could follow the wave of free trade without imposing protection assessment such anti-dumping measures. This paper tries to identify the possibility impacts of free flow of goods scheme on the use of anti-dumping in Indonesia. By imposing content analysis, this paper concludes that the possible effects tend to be increase or decrease the use of anti-dumping actions; and the possibility of elimination of anti-dumping measures and replacement with competition policy.
\end{abstract}

Keywords: ASEAN Economic Community, anti-dumping, Indonesia.

\section{Intisari}

Salah satu tujuan utama dari pembentukan Masyarakat Ekonomi ASEAN (MEA) adalah menciptakan perdagangan yang bebas dari hambatan. Namun demikian, tidak semua negara dapat mengikuti gelombang perdagangan bebas tanpa menerapkan kebijakan perlindungan dalam negeri seperti ketentuan anti-dumping. Tulisan ini mencoba untuk mengidentifikasi kemungkinan efek dari peredaran barang yang bebas dalam (MEA) terhadap penggunaan kebijakan anti-dumping di Indonesia. Dengan menggunakan analisis isi, tulisan ini menyimpulkan bahwa kemungkinan efek tersebut dapat menjadikan penggunaan kebijakan anti-dumping di Indonesia meningkat atau menurun, dan juga kemungkinan penghilangan kebijakan antidumping serta menggantikannya dengan kebijakan persaingan usaha.

Kata Kunci: masyarakat ekonomi ASEAN, anti-dumping, Indonesia.

\section{Pokok Muatan}

A. Introduction 488

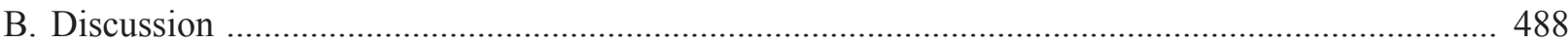

1. ASEAN Economic Community: Advantages and Challenges .................................................. 488

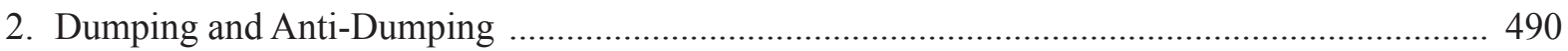

3. Possible Impact of Free Flow of Goods in AEC on the Use of Anti-Dumping Law for Indonesia

4. Probable Effect of AEC on the Elimination of Anti-Dumping Actions in Indonesia ................. 498

C. Conclusion 


\section{A. Introduction}

All the Association of Southeast Asian Nations (ASEAN) member countries have agreed to establish ASEAN Economic Community (AEC) by 2015 .This has been indicated by the ratification of the agreement of AEC blue print at the 13th ASEAN Summit in November 2007 at Singapore. ${ }^{1}$ The progression of this economic integration in the Southeast Asia region actually begins with the agreement on ASEAN Preferential Trading Arrangements (PTA) ${ }^{2}$ in 1977 and is followed by the ASEAN Free Trade Area (AFTA) in 1992.

As for the realization of economic integration that is contained in the ASEAN Vision 2020, AEC will implement one of the main pillars, which is the free flow of goods by 2015 where the interaction of goods movement in ASEAN member countries will run without any barriers whether tariff or non-tariff. In fact, the efforts to establish ASEAN as a region with the free flow of goods within the AEC scheme is a continuation and refinement of the existing schemes, namely ASEAN Preferential Trading Arrangements (PTA) in 1977 and the ASEAN Free Trade Area (AFTA) in 1992. Even though, there is a fundamental difference between those schemes in encouraging the free flow of goods in ASEAN. The PTA and AFTA are more prominent on the reduction and elimination of tariff barriers, while AEC puts more emphasis on the reduction and elimination of non-tariff barriers ${ }^{3}$ such as custom surcharges, technical measure and product characteristic requirements, and monopolistic actions in order to create trade liberalisation through a single market.

It is generally argued that a single market has many advantages such as the production efficiency and the increased productivity. ${ }^{4}$ However, considering the differences of economic and sociopolitical development in ASEAN member countries, implementing a single market may observably have significant impacts on anti-dumping law for Indonesia. ${ }^{5}$ The impacts that might occur are whether the free flow of goods in AEC may increase or reduce the use of anti-dumping actions in order to protect Indonesian domestic industry; whether a single market in AEC would encourage Indonesia to eliminate anti-dumping measures and replace it with competition law in order to achieve the main purpose of free trade in ASEAN.

Therefore, the questions that would be answered in this paper are: to what extent would the implementation of free flow of goods in the AEC era affect the practice of anti-dumping actions in Indonesia? Would it encourage Indonesia to strengthen its competition law? This paper will analyse two issues regarding with the possible impact of free of flow goods in the AEC on antidumping law in Indonesia. First, this paper will analyse the possible impact of free flow of goods in AEC on the application of anti-dumping measures for Indonesia. Second, the issues regarded with the probability effect of AEC on the elimination of antidumping policy in Indonesia will be discussed.

\section{B. Discussion}

1. ASEAN Economic Community: Advantages and Challenges

The best term that would be used by ASEAN member countries to describe their consensus about

ASEAN, "Declaration on the ASEAN Economic Community Blueprint", http://www.asean.org/news/item/declaration-on-the-aseaneconomic-community-blueprint, accessed on 13 February 2015.

ASEAN, "Agreement on the ASEAN Preferential Trading Arrangements", http://agreement.asean.org/media/download/20140119163517. $p d f$, accessed on 13 February 2014. See also Ooi Guat Tin, "The Preferential Trading Arrangements (PTA): An Analysis of Potential Effects on Intra-ASEAN Trade", Research Note and Discussion Paper ASEAN Economic Research Unit, Institute of Southeast Asian Studies, No. 26, 1981, pp. 1-2.

Association of Southeast Asian Nations, "Non-Tariff Barrier", http://www.asean.org/communities/asean-economic-community/item/nontariff-barriers, accessed on 13 February 2015.

4 Denis Hew, "Economic Integration in East Asia: An ASEAN Perspective", UNISCI Discussion Paper Institute of Southeast Asian Studies, No. 11, May 2006, pp. 49-50.

In the arena of ASEAN trade, Indonesia tends to be a big market of the ASEAN trading due to the huge number of the population. It is also known that Indonesia recently has achieved a high rate of economic growth among ASEAN countries. So, it is important to make Indonesia as an object of the anti-dumping analysis in order to examine the readiness of Indonesia to face the AEC as well as to protect local industries. See: Howard Gumilang et al., "Economic and Environmental Impacts of Trade Liberalization: The Case of Indonesia", Economic Modelling, No. 28, 2011, p. 1031. 
regional economic integration in South East Asian is ASEAN Economic Community. It also represents the main goal of the ASEAN 2020 vision that is the creation of economic bloc where there is free flow of goods, services, capital, investment and the balancing of economic growth as well as reducing poverty and socio-economic gaps. This formation of economic integration has been designed through several annual ASEAN meeting since 2003 such as Bali Summit, ASEAN Economic Meeting in 2006 and $12^{\text {th }}$ and $13^{\text {th }}$ ASEAN Summit in $2007 .^{6}$

To implement the AEC, it must refer to the AEC blueprint, which fundamentally has four key features and core elements. ${ }^{7}$ The first feature is about single market and production base that covers seven instruments such as free flow of goods, services, investment, capital, skilled labour, priority of integration sector and food, agriculture and forestry. The second is about competitive economic region, which includes six elements of application like competition policy, consumer protection, intellectual property rights, infrastructure development, taxation and E-Commerce. The third character is equitable economic development that contents two approaches such as Small and Medium Enterprises (SME) development and Initiative for ASEAN integration. The last core element of AEC blueprint is about integration into global economy that has two strategies like coherent approach towards external economic relations and enhances participation in global supply networks. ${ }^{8}$

There are at least five advantages that might arise from AEC. ${ }^{9}$ First, AEC literally would increase the efficiency balances, the dynamic synergy and competitiveness of ASEAN members as well as will create more regional cooperation. Therefore, it would make every interaction and movement of goods, services, investment, capital and people more practicable and not difficult. Finally, it will establish the gate to new market for recognized products. In other words, it would provide first-hand systems of organizing the sequences of supply.

Second, AEC would invite foreign investors because with AEC every ASEAN nation becomes more important for investment in a single market that could be recognized as a larger regional market with about 600 million people. In addition, with the endeavour to expand to zero tariffs on almost all goods by 2015, AEC provide the opportunities for all ASEAN countries to remain involved in the global economy through regional-level free trade agreements, for instance, Free Trade Agreement between ASEAN and Australian and New Zealand, Japan, China, Korea and India.

Third, in the long terms, AEC will create the advanced competition to developed countries. This is because the AEC is more needed for investment in emerging markets than in the US and Europe. Therefore, ASEAN countries would be storage of income that might benefit some countries and could lead the developed countries in terms of competition. ${ }^{10}$

Forth, AEC would benefit the development of SMEs across ASEAN by integrating and supporting them in the initial period. By doing so, the SMEs would stimulate the economic growth for each ASEAN member country. Fifth, AEC would create a big prospect for Tourism in ASEAN countries. Thus this opportunity could lead the countries to get more income and create jobs for the people. ${ }^{11}$

Despite those benefits, AEC tends to face many challenges such as the problem of utilization

\footnotetext{
See Ludo Cuyvers et al, "From AFTA towards an ASEAN Economic Community And Beyond", CAS Discussion Paper Central for ASEAN Studies, No. 46, January 2005, pp. 9-10.

S. Urata and M. Okabe, "Tracing the Progress Toward the ASEAN Economic Community: Overview Chapter 1", in S. Urata and M. Okabe (Ed.), "Tracing the Progress Toward the ASEAN Economic Community", Research Project Report 2009 Economic Research Institute for ASEAN and East Asia, No. 3, 2010, p. 6.

See ASEAN Secretariat, 2008, ASEAN Economic Community Blueprint, ASEAN Secretariat, Jakarta, pp. 6-26.

Kuboon Charumanee, "ASEAN Economic Community (AEC) 2015 and Its Implication on APEC", Paper, The Annual Conference for the APEC Study Center Consortium, Kazan, Russia, 26-27 May 2012, pp. 45-46.

10 Christopher W. Runckel, “Asia Opportunities: ASEAN Economic Community (AEC) in 2015”, http://www.business-in-asia.com/asia/asean_ economic_community.html, accessed on 24 February 2015.

11 Charumanee, Loc.cit.
} 
rates of FTA tariff preferences that remain low in goods sector, the problem of ASEAN member countries effort to ensure the target in service sectors could be achieved, the problem of regulatory and constitutional restrictions for ASEAN countries regarding overseas employments in the aspect of skilled labour mobility in ASEAN, and the problem of uncertainties of investor regulation and protection in some ASEAN countries. ${ }^{12}$

In addition, the realization of tariff reduction is not followed by non-tariff barriers implementation that has made little progress. As a result, there is an increased concern regarding non-tariff barriers due to its role as tariff replacement to protect domestic industries. Moreover, in the scheme of comprehensive production linkage, it is necessary for ASEAN countries to maintain an efficiency of moving goods between countries as well, in order to create trade opportunities from the interaction within the network. Furthermore, it seems that there has been an increase of the implementation of protectionism since the recent global economic crisis. $^{13}$

\section{Dumping and Anti-Dumping}

Although many sources define the term 'dumping', in essence, there is no different definition for this term. It is basically a price discrimination against similar products, where the export price is lower than the domestic price, which might cover a fraudulent practice that can lead to distortions in international trade. For instance, Peter Van Den Bossche gives the definition of dumping as below, "Dumping is a situation of international price discrimination involving price and the cost of an item in the exporting country in relation to the price of the goods in the importing country". ${ }^{14}$
Moreover, if it refers to the WTO provisions, dumping could be said to occur when the price of export products is cheaper than its normal value, which is less than the price for the sale of a like product in the local market. ${ }^{15}$ Despite the definition, dumping could be classified into many different types. According to Jacob Viner there are three types of dumping circumstances: first is sporadic dumping which could be seen as a condition where there is a motivation to dispose of goods for a shortrun to get rid of surplus shock. Thus, this type tends to be harmful that might result in damage to either the exporting or importing countries. The second type is intermittent dumping. This variety seems to be temporary and it occurs through entering a new market, holding back within the market share or evicting the competitors from the market. Thereby, Jacob Viner assumes that it does not necessarily seem to cause a serious injury for the domestic market industry. The third is long-term or continuous dumping. Long-term or continuous dumping is driven by the determination to extend or retain full production in wide-ranging economies. ${ }^{16}$

In fact, according to World Trade Organization (WTO) rules, it can be said that it is permissible to do dumping because is not unlawful. As a consequent, it is not an obligation for any member country of the WTO to have an antidumping system. This is because WTO agreement does not deliberately force the parties to apply anti-dumping actions, which means that the only purpose of the agreements is to prevent the WTO member countries in using anti-dumping actions for trade defence and protectionism that might lead to the destabilisation of free trade. However, since 1947, there has been an argument of whether

12 Siow Yue Chia, "The ASEAN Economic Community: Progress, Challenges and Prospects", ADBI Working Paper Series Asian Development Bank Institute, No. 440, 2013, pp. 14-15.

13 M. S. Austria, "Non-Tariff Barriers: A Challenge to Achieving the ASEAN Economic Community", in S.B. Das et al. (Ed.), 2013, the ASEAN Economic Community: A Working in Progress, Institute of Southeast Asian Studies, Singapore, p. 31.

14 Peter Van den Bossche, 2008, The Law and Policy of the World Trade Organization: Text, Cases and Materials, 2nd Ed, Cambridge University Press, New York, p. 516.

15 See Marrakesh Agreement Establishing the World Trade Organization, opened for signature 15 April 1994,1867 UNTS 187 (entered into force 1 January 1995) annex 1A ('GATT 1994') Article 6.

16 Thomas J. Schoenbaum, "Antidumping and Countervailing Duties and the GATT: An Evaluation and Proposal for a Unified Remedy for Unfair International Trade", German Y.B.I.L, No. 30, 1987, p. 179. 
or not the General Agreement on Tariffs and Trade (GATT, predecessor to the WTO) should cover the prohibition of anti-dumping even though it was not bad. For example, when GATT was negotiated, there was an argument from the United Kingdom that strongly urged GATT to prohibit anti-dumping measures though dumping itself was not bad. ${ }^{17}$

In addition, although dumping is not illegal, the use of anti-dumping actions in the global scope was actually uncommon before the Tokyo round for GATT negotiations in 1979 where amendments to the associated anti-dumping provisions undergone. Nonetheless, after 1980 the increase use of antidumping measures began due to the changes of anti-dumping provisions as well as the decrease of tariffs and quotas as traditional trade barriers during the 1980s and 1990s. ${ }^{18}$

On the other hand, some scholars still argue that dumping is unfair because it might be hard or event tends to be impossible to sell the products that have same quality with the equal price. It is reasonably outlandish if the prices of identical product in features should be sold equally everywhere. Indeed, tariff, market size and demand structure tend to make product prises differ across markets. Thereby dumping could be identified as price discrimination in common business practice. Nevertheless, this practice would be acceptable in the domestic market, and accordingly it could also be done internationally. ${ }^{19}$ For example, if someone could sell the concert ticket to teenagers and school students at a cheaper price than for adults, why is it bad to sell medicines in Uganda at a price less than in the United States? ${ }^{20}$

Despite the discussion above, since 1 January 1995 the WTO has ruled the multilateral trading system regarding to anti-dumping provisions, which are found in the following articles: the first is Article VI of GATT 199421, which is the permission provision and encloses the basic provisions relating to anti-dumping actions; the second is the Anti-Dumping Agreement. ${ }^{22}$ This agreement contents the implementation provisions of Article VI of GATT 1994 particularly in detailed requirements concerning methods and procedural issues. Accordingly, both tend to be considered as legal frameworks of anti-dumping under WTO provisions. ${ }^{23}$

As for the legal instruments, both GATT 1994 Article VI and the Anti-Dumping Agreement should be referred to as one legal source. To impose this provisions, before taking the anti-dumping actions it is strongly required to apply three basic preconditions under GATT 1994 Article VI. These preconditions should be met with the condition where the country would enforce the anti-dumping action. Thus, the WTO member countries must have determination in these three basic preconditions, which are: first, it should be a dumped import product that are in question; second: that should be a material injury for its own industry, or the country is threatened with a material injury, or that

Bruce A. Blonigen and Thomas J. Prusa, “Antidumping”, Working Paper, National Bureau of Economic Research, 2001 , p. 2.

Stephen Kirchner, "Time to Dump Australia's Anti-Dumping System”, Issue Analysis The Centre for Independent Studies, No. 141, 2013, p. 4.

19 Sarut Wittayarungruangsri, "Antidumping: A Villain in International Trade", http://economics.about.com/cs/moffattentries/a/antidumping. htm, accesses on 23 February 2015.

20 Ibid.

21 Article VI (1) of GATT 1994 states that The contracting parties recognize that dumping, by which products of one country are introduced into the commerce of another country at less than the normal value of the products, is to be condemned if it causes or threatens material injury to an established industry in the territory of a contracting party or materially retards the establishment of a domestic industry. For the purposes of this Article, a product is to be considered as being introduced into the commerce of an importing country at less than its normal value, if the price of the product exported from one country to another: (a) is less than the comparable price, in the ordinary course of trade, for the like product when destined for consumption in the exporting country, or (b) in the absence of such domestic price, is less than either: (i) the highest comparable price for the like product for export to any third country in the ordinary course of trade, or (ii) the cost of production of the product in the country of origin plus a reasonable addition for selling cost and profit. Due allowance shall be made in each case for differences in conditions and terms of sale, for differences in taxation, and for other differences affecting price comparability.

22 Article 1 States that an anti-dumping measure shall be applied only under the circumstances provided for in Article VI of GATT 1994 and pursuant to investigations initiated 1 and conducted in accordance with the provisions of this Agreement. The following provisions govern the application of Article VI of GATT 1994 in so far as action is taken under anti-dumping legislation or regulations.

23 J. Czako et al. (Ed.), 2003, World Trade Organization: A Handbook on Anti-Dumping Investigations, Cambridge University Press, U.K., p. 2. 
the establishment of a domestic industry is being materially retarded; and third is that the injury under the second condition above is being caused by the dumped imports. Ultimately, if these three qualifications are fulfilled, dumping might be counteracted.

Although the signatory of the Anti-Dumping Agreement (AD Agreement) are also the same with all Members of the WTO, it is not binding for Members to impose a legal basis for anti-dumping action, or to take anti-dumping action when, or if, detrimental dumping emerges. Even though, the AD Agreement denotes that if a Member prefers to take anti-dumping action, they should be able to follow the related provisions and shall be preceded by the prerequisite investigation conducted based on the AD Agreement provisions. ${ }^{24}$ Once the member is granted the anti-dumping actions, there are only three measures allowed by the AD Agreement, the first is provisional measures, the second is definitive anti-dumping duties, and the third is price undertakings. ${ }^{25}$

\section{Possible Impact of Free Flow of Goods in} AEC on the Use of Anti-Dumping Law for Indonesia

\section{a. Free Flow of Goods in AEC}

Free flow of goods in the AEC blueprint tends to be considered as a principal component in the engine of a single market establishment. As what has been stated in the ASEAN blueprint, a single market for goods would benefit and facilitate the growth of production networks in the ASEAN. Thereby, free flow of goods is regarded as a crucial instrument. As for essential means, the free flow of goods covers, what in the ASEAN blueprint indicated, a comprehensive scope of issues that are related to tariffs elimination among ASEAN goods, abolition of non-tariffs barriers, rules of origin, trade facilitation by customs procedures and related information flows, customs integration, the ASEAN Single Window, and standards and technical barriers. ${ }^{26}$

Indeed, the free flow of goods has been implemented since 2008 particularly in the scope of tariff reduction and elimination of tariffs. For instance, the reducing and eliminating tariffs to $0.5 \%$ for each member ASEAN country and even zero rates of common effective preferential tariffs (CEPT) for ASEAN 5 and Brunei, which was 2,6\% in 2010 for Cambodia, Laos, Myanmar and Vietnam. ${ }^{27}$ Although there are still obstacles to the free flow of goods especially in the elimination of non-tariff barriers and non-tariff measures, ${ }^{28}$ the progressive achievement of free flow of goods realization tends to indicate that the commitment of ASEAN countries to gain the development of economic bloc by creating a single market has been instigated.

Therefore, in 2009 all members of ASEAN countries has signed ASEAN Trade in Goods Agreement (ATIGA) in order to accelerate the implementation of free flows of goods among ASEAN nations by reducing or eliminating all tariffs and non-tariffs barriers to trade as well as harmonizing trade related procedures, standards and rules. Moreover, the elimination of economic blocks apart from creating profounder economic linkages within ASEAN is also projected to help inferior business expense, endorse economies

\footnotetext{
See Agreement on Implementation of Article VI of the General Agreement on Tariffs and Trade 1994, open for signature 15 April 1994,1868 UNTS 201 (entered into force 01 January 1995) Article 1.

Ibid Article 7, 8, 9 and 17(4).

See ASEAN Secretariat, Op.cit., pp. 6-10.

The Economic Research Institute for ASEAN and East Asia (ERIA), 2012, Mid-Term Review of the Implementation of the AEC Blueprint Executive Summary, The Economic Research Institute for ASEAN and East Asia (ERIA), Jakarta, pp. 7-11.

28 Syetarn Hansakul, "ASEAN Economic Community (AEC) A Potential Game Changer for ASEAN Countries", https://www.dbresearch.com/ PROD/DBR_INTERNET_EN-PROD/PROD0000000000315342/ASEAN + Economic + Community $+(A E C) \% 3 A+A+$ potential + game + change $r+$ for $+A S E \bar{A} N+$ countries.pdf., accessed on 14 February 2015.
} 
of balance and competitive business and improve general economic productivity in the region.

In 2010, a year after signing ATIGA the effect of free flows of goods toward the real economic growth for ASEAN countries apparently does not seem to be a positive progress. It could be said, however, that the performance of the ASEAN's ten economies has been substantially imbalanced due to the heterogeneity of ASEAN population, per capita income and economic structure. The economic growth trend in ASEAN countries tends to be fluctuated. Even though, ASEAN has strong on average of real GDP progression at a 5\% annual rate from 1990 until 2010 particularly in Indonesia, which is known as the region's largest economy among ASEAN countries and has commenced inclusive political and economic changes. ${ }^{29}$

\section{b. Indonesia Anti-Dumping Law}

As a part of WTO members and AD Agreement parties, Indonesia has regulated Anti-dumping measurements in line with the GATT 1994 Article VI and the AD Agreement. At the beginning of the antidumping provisions, it laid out in Law No. 10/1995 on Customs particularly in Article 18 to Article 20 and subsequently converted into Law No. 17/2006 on Amendments to Law No. 10/1995 on Customs. In that regard Indonesian government subsequently issued several regulations that govern three matters regarding anti-dumping.

First, substantial matters such as normal value and market injury that are regulated in Government Regulation No. 34/2011 on Anti-Dumping measures, Countervailing Measures and Safeguard Measures;
Second, procedural provisions like the procedure of investigation and the process of filing the petition, which are governed under Decree of the Minister of Industry and Trade No. 261/MPP/Dec/7/2001 on Procedures and Filing Requirements and Investigation Over Dumping Goods and Goods Containing subsidies. ${ }^{30}$ This rule has been applied in the case of anti-dumping petition for wheat flour from Australia, Sri Lanka and Turkey in October $16^{\text {th }} 2008$ that had been imposed by employers association of white flour. ${ }^{31}$

Third, in terms of Indonesia antidumping institution, the regulations issued are the Decree of the Minister of Industry and Trade No. 427/MPP/Dec/10/2000 on Anti-Dumping Committee of Indonesia. This decree is subject to the establishment and the formation of anti-dumping committee of Indonesia; the Decree of the Minister of Industry andTradeNo.428/MPP/Dec/10/2002 of Appointment and Appointment of Members of the Anti-Dumping Committee of Indonesia. This decree is imposed for specific matter in selection and promotion of the committee member; and Circular Letter of Directorate General of Customs and Excise SE-19/BC/1997 on Guidelines for Polling Temporary Anti-Dumping Duties. ${ }^{32}$

\section{c. The Practice of Anti-Dumping Actions in Indonesia}

According to the Decree of the Minister of Industry and Trade No. 427/MPP/ Dec/10/2000 on Anti-Dumping Committee of Indonesia, Indonesian Anti-Dumping Commission must resolve all dumping case. This Committee has been established in 1996 with the main tasks to conduct investigations into allegations of dumping goods and

29 See P. A. Petri, “Asia and the World Economy in 2030: Growth, Integration, and Governance”, in A. J. Tellis et al. (Eds.), 2010, Strategic Asia: Asia's Rising Power and America's Continued Purpose, The National Bureau of Asian Research, Seattle, pp. 59-60.

30 Imam Kharisma Makkawaru, 2012, Implementation of Anti-Dumping Law in Indonesia as Trade Remedies in the Frame of International Law, Thesis, University of Indonesia, Jakarta, p. 68.

Ibid, p. 122

Ibid. 
goods containing subsidies or cause harm to the domestic industry of similar goods. Since 1996, this committee has handled 42 dumping cases until June 2012.33

Table 1. Dumping Cases in Indonesia 1996 - 2012
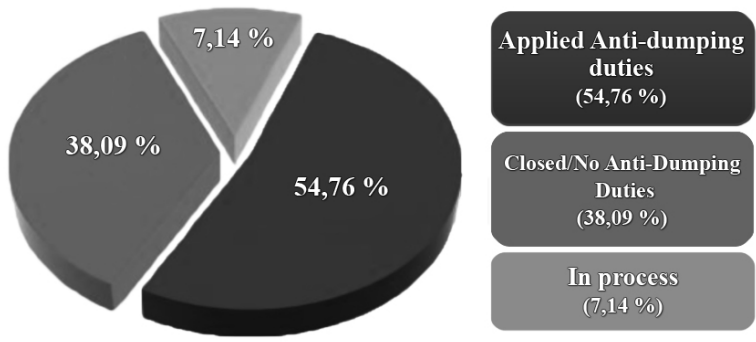

Source: Indonesian Anti-Dumping Committee, 2012.

Meanwhile, according to the WTO anti-dumping statistic report, as shown in the table 2 below, Indonesia has the highest percentage of anti-dumping actions among ASEAN countries.

Table 2. Anti-Dumping Report Measurement by Reporting Member in ASEAN 1995 - 2013

\begin{tabular}{|l|r|c|}
\hline $\begin{array}{c}\text { ASEAN } \\
\text { Countries }\end{array}$ & $\begin{array}{c}\text { AD by } \\
\text { Reporting } \\
\mathbf{1 9 9 5} \text { - 2013 }\end{array}$ & Percentage \\
\hline Brunei & 0 & - \\
\hline Cambodia & 0 & - \\
\hline Indonesia & 43 & 33 \\
\hline Lao & 0 & - \\
\hline Malaysia & 34 & 26 \\
\hline Myanmar & 0 & - \\
\hline Philippines & 11 & 8 \\
\hline Singapore & 2 & 2 \\
\hline Thailand & 42 & 32 \\
\hline Vietnam & 0 & - \\
\hline Total & 132 & 100 \\
\hline
\end{tabular}

Source: WTO Statistic on Anti-Dumping, 2013. ${ }^{34}$
In addition, table 3 below shows that there are 5 exporting countries from ASEAN that have been reported by Indonesia due to dumping issues. $37 \%(\mathrm{~N}=16)$ of the total of Indonesia anti-dumping report $(\mathrm{N}=43)$ that has been made is intended to those 5 ASEAN Countries.

Table 3. Indonesia Anti-Dumping Initiation Report among ASEAN Exporting Countries 1995 - 2013

\begin{tabular}{l|c}
\hline $\begin{array}{c}\text { Exporting Countries } \\
\text { from ASEAN }\end{array}$ & $\begin{array}{c}\text { Indonesia AD Initiative } \\
\mathbf{1 9 9 5 - 2 0 1 3}\end{array}$ \\
\hline Malaysia & 5 \\
\hline Philippines & 1 \\
\hline Singapore & 4 \\
\hline Thailand & 5 \\
\hline Vietnam & 1 \\
\hline Total & 16 \\
\hline
\end{tabular}

Source: WTO Statistic on Anti-Dumping, 2013. ${ }^{35}$

Accordingly, it can be concluded that there are three interpretation points from the data shown above. First: among ASEAN countries, it seems that Indonesia has been frequently using the anti-dumping law. Second: although Indonesia is a part of ASEAN free trade agreements, it does not mean that Indonesia could not use the antidumping law. In fact, 5 of ASEAN member countries have been reported by Indonesia due to dumped goods. Third: the high use of anti-dumping law tends to show that many imported goods have flooded Indonesia. 


\section{d. Relationship between Free Flow of Goods and the Practice of Anti- Dumping}

There are many studies that have analysed the link between the establishing of RTAs and potential modifications in anti-dumping configurations. For instance, many scholars argue that the creation of regional economic integration results in an intensification of anti-dumping uses that directs to non-member countries. ${ }^{36}$ Nevertheless, other study shows that the elimination of anti-dumping provisions might lead to the condition below, "An increase in anti-dumping protection directed towards non-members when in fact the injury to domestic industry mostly stems from imports from other [RTA] members". ${ }^{37}$

Despite that fact, in general, the creation of regional integration obviously aims to establish a free and fair trade that basically will include the removal of all trade barriers. ${ }^{38}$ However, the WTO still allow the use of trade remedies like anti-dumping, antisubsidy and safeguard measurement, which might become a stumbling block for the free trade. ${ }^{39}$ This is because of the retaliatory motives. ${ }^{40}$ Hence the use of trade remedies has been increasing among WTO member countries. ${ }^{41}$

On the other hand, since the world economic crisis in 2008, all countries in the world seem to increase their protectionism through several instruments including anti-dumping actions. The wave of trade remedies used remains to flourish amongst the 153 WTO members and the demand of protectionism is needed by either developed or developing countries. ${ }^{42}$ In addition, the theory of political economy of protection acknowledges that the winner countries would not compensate the loosing countries in the free trade arena, however these loosing countries have an "incentive to strive for protection through the political process of trade policy making." $" 43$

In fact, all member country of any regional trade agreement generally tends to maintain the use of trade remedy including anti-dumping measures. Otherwise, they enact the rules governing such use. Thus, it seems that the prohibitions of trade remedies are uncommon. This can be seen from the survey of trade remedy provisions in Regional Trade Agreements (RTAs). The sample size of this survey was seventy-four RTAs that were selected based on geographic variety, economic impact, and newness. The findings of this survey showed that there were only thirteen RTAs that absolutely included the prohibition of at least one of trade remedies. European Union is the only RTAs of these thirteen, which has prohibited the use of antidumping, countervailing duties, and

36 J. Bhagwati and A. Panagariya, "Preferential Trading Areas and Multilateralism: Strangers, Friends or Foes?", Discussion Paper Series Department of Economics Columbia University, No. 9596-04, 1996; and also see Prusa and Teh, "Protection and Diversion Reduction: PTAs and the Incidence of Antidumping Disputes", NBER Working Paper, No. 16276, 2010, p. 1 and p. 19.

37 World Trade Report, 2011, The WTO and Preferential Trade Agreements: From Coexistence to Coherence, World Trade Organization, Geneva, p. 178.

38 J. Ravenhill, '"Regional Trade Agreements", in J. Ravenhill (Ed.), 2011, Global Political Economy, Oxford University Press, London, pp. 142, $149,163$.

39 Ryan Farha, "A Right Unexercised is A Right Lost? Abolishing Anti-Dumping in Regional Trade Agreements", Georgetown Journal of International Law, No. 44, 2012, p. 211.

40 Alberto Martin and Wouter Vergote acknowledge that retaliatory motives are those carried out by a country against trading partners that have in turn used anti-dumping against it in the past. See Alberto Martin and Wouter Vergote, "On the Role of Retaliation in Trade Agreements", Journal of International Economics, No. 76, 2008, p. 74.

${ }^{41}$ James C. Hartigan and Hylke Vandenbussche, "Why Does the WTO have an Anti-Dumping Agreement?", Discussion Papers LICOS Centre for Institutions and Economic Performance, No. 253, 2010, pp. 2-3.

42 Dan Wei, "Antidumping in Emerging Countries in the Post-Crisis Era: A Case Study on Brazil and China", Journal of International Economic Law, No. 16, 2013, p. 922.

43 P.K.M. Tharakan, “Political Economy and Contingent Protection”, The Economic Journal, Vol. 105, No. 433, 1995, p. 1550, $1551,1552$. 
safeguards. ${ }^{44}$

From this finding, it can be said that - in terms of the link between free trade and the use of anti-dumping - most regional trade agreements tend to have the provision of antidumping, countervailing and safeguards. This might lead to the increase of anti-dumping actions that could be imposed by the member countries of the RTAs. ${ }^{45}$ Accordingly, it could be said that although the aim of free trade implementation is eliminating trade barriers, it seems that free trade agreement would affect the member countries to enforce antidumping measures.

Table 4. Elimination Trade Remedies in Current RTAs ${ }^{46}$

\begin{tabular}{|c|c|c|c|c|c|c|}
\hline RTA & $\begin{array}{r}\text { Type of } \\
\text { agreement }\end{array}$ & $\begin{array}{r}\text { Anti-dumping } \\
\text { measures } \\
\text { prohibited }\end{array}$ & $\begin{array}{r}\text { Anti-subsidy } \\
\text { measures } \\
\text { prohibited }\end{array}$ & $\begin{array}{c}\text { Safeguard } \\
\text { measures } \\
\text { prohibited }\end{array}$ & $\begin{array}{r}\text { Competition } \\
\text { Chapter }\end{array}$ & $\begin{array}{r}\text { Date the } \\
\text { elimination of } \\
\text { anti-dumping } \\
\text { measures came } \\
\text { into force }\end{array}$ \\
\hline European Union (EU) & $\mathrm{CU}$ & $x$ & $x$ & $x$ & $x$ & $01 / 01 / 1958$ \\
\hline Australia-New Zealand & FTA & $x$ & & $x$ & $x$ & $01 / 07 / 1990$ \\
\hline EU-Andorra & CU & $x$ & $x$ & $x$ & & $01 / 07 / 1991$ \\
\hline EU-San Marino & CU & $x$ & $x$ & $x$ & & $01 / 04 / 2002$ \\
\hline EU-EFTA, European Economic Area (EEA) & FTA & $x$ & $x$ & & $x$ & $01 / 01 / 1994$ \\
\hline Canada-Chile & FTA & $x$ & & & $x$ & 05/07/1997 \\
\hline European Free Trade Association (EFTA) & FTA & $x$ & $x$ & & $x$ & $01 / 06 / 2002$ \\
\hline EFTA-Singapore & FTA & $x$ & & & $x$ & $01 / 01 / 2003$ \\
\hline EFTA-Chile & FTA & $x$ & $x$ & & $x$ & $01 / 12 / 2004$ \\
\hline China-Hong Kong & FTA & $x$ & $x$ & & & $01 / 01 / 2004$ \\
\hline China-Macau & FTA & $x$ & $x$ & & & $01 / 01 / 2004$ \\
\hline
\end{tabular}

Source: Thomas J. Prusa, 2005 and J.D. Rey, 2012.

However, some scholars argue that the removal of trade remedy measures, in particular, anti-dumping actions and antisubsidy measures, is occasionally needed referring to Article XXIV of the GATT particularly in Paragraph 8(a) and (b).This provision governs the requirement of removal duties and other rules limiting trade for RTA. ${ }^{47}$ Even though, the exception of some GATT articles from the general requirement to remove all trade barriers is allowed by the Article XXIV. ${ }^{48}$

Indeed, there is an ambiguity in the content of the articles that may be excluded in RTAs. It explicitly can be seen that the articles on trade remedy mechanisms like Article VI for anti-dumping and/or anti-subsidy measures and Article XIX for safeguard measures, does not appear among the articles that may be excluded in the RTAs. It seems that there is no an intention to permit Article VI to be excluded in RTAs because there is no a reference to the article in the Paragraph. ${ }^{49}$ Hence, the interpretation might arise from the lack of trade remedy Articles from the list of excluded articles tends to suggest that

\footnotetext{
Robert Teh et al., "Trade Remedy Provisions in Regional Trade Agreements”, Staff Working Paper ERSD, No. 3, 2007, pp. 18-19.

Thomas J. Prusa, “Anti-Dumping: A Growing Problem in International Trade”, The World Economy, Vol. 28, No. 5, 2005 , p. 683.

Ibid and also see J.D. Rey, "Anti-Dumping Regional Regimes and The Multilateral Trading System: Regional Antidumping Regimes Do Make a Difference?”, Staff Working Paper ERSD, No. 22, 2012, pp. 37-48.

48 The article states that free-trade area shall be understood to mean a group of two or more customs territories in which the duties and other restrictive regulations of commerce (except, where necessary, those permitted under Articles XI, XII, XIII, XIV, XV and XX) are eliminated on substantially all the trade between the constituent territories in products originating in such territories.

49 Alberto Martin and Wouter Vergote, Loc.cit.
}

47 Ibid. 
the use of trade remedy mechanisms in RTAs may be inconsistent with GATT rules. As a result, this ambiguity is likely to indicate the conditional impact of RTAs on anti-dumping uses. It depends on the explicit rule in the list of excluded articles whether or not the trade remedy instruments need to be eliminated upon the formation of RTAs. ${ }^{50}$

In the context of AEC, the trade remedy particularly in anti-dumping does not appear in the blueprint of the AEC. However, when it refers to ATIGA as the basis of free flow of goods, it can be seen that there is provision of trade remedy use. In particular, Chapter 9 of ATIGA allows all member countries the use of safeguards measures, ${ }^{51}$ anti-dumping, subsidies and countervailing measures. ${ }^{52}$ Even though, it does not mean that the consent of using anti-dumping actions may lead to either increase or decrease of anti-dumping uses among ASEAN member countries.

According to the European Union (EU) experiences regarding the abolition of anti-dumping measures, a study observes that the elimination of anti-dumping provision in EU does not accelerate the alleged dumping practice between EU countries. It also does not increase the number of anti-dumping measures against third countries. ${ }^{53}$

The EU experiences above could not be compared to AEC. This is because there is a big different of circumstances between both RTAs particularly in the economic significance and geographical diversity. This circumstance also seems to challenge the implementation of free flows of goods. For instance, Indonesia with the diversity of geographic area and a big population as well as the prospective of economic growth tends to be affected by this free trade agreement especially in the use of anti-dumping law. It might be said that Indonesia would remain use actively the anti-dumping actions in this AEC era even though there is still some weaknesses regarding to the domestic legal framework for anti-dumping. ${ }^{54}$

On the other hand, it could also be said that free trade in AEC may affect the reduction of Indonesia anti-dumping actions due to domestic problem such as corruption and lack of law enforcement particularly in anti-dumping law. Corruption in Indonesia becomes an epidemic that would be a stumbling block in participating at AEC implementation. ${ }^{55}$ In the context of antidumping actions, corruption might lead to the scepticism of people in industrial sector to enforce the petition of dumping issues. Ultimately, it could reduce the practice of anti-dumping action in Indonesia.

In addition, the lack of law enforcement in anti-dumping law may decrease the use of Indonesia anti-dumping measures. This because of two things: first is the lack of the essence of anti-dumping law, which means that the law tends to be not applicable and the second is the lack of anti-dumping enforcer in the anti-dumping committee, which means that the enforcer is likely supposed to be ineligible to be appointed in the committee. ${ }^{56}$

See ASEAN Trade in Goods Agreement, opened for signature 26 February 2009 (entered into force 17 Mei 2010 ) Article 86.

Ibid, Article 87.

Jonas Kasteng and Camilla Prawitz, "Effects on Trade and Competition of Abolishing Anti-Dumping Measures: The European Union Experience", Kommerskollegium National Board of Trade, No. 6, 2013, pp. 8-11.

54 See Makkawaru, Op.cit, p. 161.

55 Junianto James Losari and Joseph Wira Koesnaidi, "Indonesia and the Establishment of the ASEAN Economic Community in 2015: Are We There Yet?", Policy Brief Asian Development Bank, No. 10, 2014.

56 Sulistyo Widayanto, 2007, Negosiasi untuk Mengamankan Kepentingan Nasional di Bidang Perdagangan, Ditjen KPI, Jakarta, pp. $1-7$. 
4. Probable Effect of AEC on the Elimination of Anti-Dumping Actions in Indonesia

\section{a. Is It Possible to Eliminate Anti-} Dumping in the AEC?

Without a doubt that anti-dumping uses grow vigorously. Nonetheless, it still remains debatable particularly in the sense of the fairness of this measurement. Some might say that dumping may be risky for national manufacturers as a practice of inequitable competition. Others could argue that it may benefit domestic consumers and producers that involve foreign products in further production from lower prices.

Despite all arguments above, it clearly can be argued that the elimination of antidumping actions in the AEC is impossible. This is because the trade remedies measures provisions are literally included in the ATIGA. Hence, none of ASEAN member countries could remove the anti-dumping actions. It is only allowed for any member countries whether or not to use the antidumping actions because it is rights that must be respected by every member.

For instance, in February 2013, Malaysia forced anti-dumping duties on Indonesia Company that exported steel wire rods to Malaysia. In March 2013, Indonesia enforced anti-dumping duties on the imports of cold rolled coil and sheet from Vietnam. ${ }^{57}$ Both examples reflect the respect of ASEAN member countries to the rights to use of antidumping actions.

On the other hand, there are some regional trade agreements that have removed the use of anti-dumping actions.
This elimination has been explicitly done through three ways. First: by deliberately mentioning the elimination in the legal text like Article 26 of European Economic Area (EEA), Article 36 of European Free Trade Agreement (EFTA), and Article 16 of EFTASingapore. Second: by legal texts on WTO plus provisions on anti-dumping measures such as Article 9 of Singapore New Zealand and Article 2.8 of Singapore-Jordan. Third: by legal text with 'best endeavour' clause to not impose anti-dumping measures, for example Article 2.10 paragraph 1 of EFTA South Korea. ${ }^{58}$

However, as a matter of fact, the findings from the survey above that involved seventy four regional trade agreements in the world indicate that approximately $90 \%$ of the number of regional trade agreements in the world do not eliminate the trade remedies measurement particularly in anti-dumping provision. ${ }^{59}$ In addition, other study shows that in general most PTAs implement singular or supplementary rules on trade remedy actions against members' trade. ${ }^{60}$ This is because anti-dumping courses become the top prominence for the developing world. ${ }^{61}$

Considering other experiences from other regional trade agreements like what have been explained above, it could be said that those experiences might be taken into account to support the AEC arguments for imposing anti-dumping actions within member countries and it is, thereby, obviously that AEC would not affect to the elimination of anti-dumping actions.

\footnotetext{
Cassey Lee and Yoshifumi Fukunaga, "Competition Policy Challenges of Single Market and Production Base", Discussion Paper Series ERIA, No. 17, 2013, p. 17.

58 Jonas Kasteng and Camilla Prawitz, "Eliminating Anti-Dumping Measures in Regional Trade Agreements", Kommerskollegium National Board of Trade, No. 5, 2013, pp. 5-7.

59 Thomas J. Prusa, Loc.cit.

60 Thomas J Prusa and Robert Teh, "Protection Reduction and Diversion: PTAs and the Incidence of Anti-Dumping Disputes", Working Paper National Bureau of Economic Research, No. 16276, 2010, p. 10.

61 Robert M. Feinberg, “Anti-Dumping As Development Issue”, Global Economy Journal, Vol. 11, No. 3, 2011 , p. 13.
} 


\section{b. Can Competition Law Replace It?}

Before analysing the possibility of changing the anti-dumping provisions into competition policy whether in Indonesia or among ASEAN countries, it firstly would be explained the difference between competition and anti-dumping. Some fellows argue that both terms have contradictory objective. For instance, in terms of protecting domestic industry from unfair non-nationals products caused by price-discrimination, anti-dumping becomes more preferable to be used. Meanwhile, competition policy aims to protect the consumer from belowcost pricing. In addition, both have different principal concept. The former believes in fairness principal, the later considers the efficiency in economic aspect. ${ }^{52}$

From another point of view, other scholars believe that there is a general coherency in the objective of anti-dumping and competition law. For instance, competition law provides remedy cases where a like product is delivered at different prices locally. Likewise, anti-dumping law also stipulates a remedy for circumstances in which commodities are imported at less than normal value. Thereby, both antidumping and competition law take aim at the problem of discriminatory pricing. It could also be said that competition and antidumping laws regulate the legality of a particular manner using dissimilar standards. ${ }^{53}$

Accordingly, it could be said that antidumping actions and competition policies have practical differences as well as different determination services. ${ }^{54}$ However, it does not lead to the inclusion competition rules and the abolishing of anti-dumping actions in the existing regional trade agreements. Considering the existing regional trade integrations, RTAs that have eliminated the use of anti-dumping measures have tended to replace it with safeguard measures or, in certain cases, the right to include provisions on safeguards in the chapter on competition. ${ }^{55}$

Nevertheless the replacement of antidumping provision with competition policy has occurred in few free trade arrangements, although it is rarely. For instance, In AustraliaNew Zealand, EFTA-Chile and EFTASingapore, the elimination of anti-dumping measures between the parties is specifically linked to the application of provisions on competition. In other agreements, such as the EU, the EFTA, the EEA and Canada-Chile the elimination of the use of anti-dumping measures has, in practice, been replaced by the use of competition rules. ${ }^{56}$

Despite the discussion above, AEC regulates the competition policy in the blueprint of AEC under the label of competitive economic region. ${ }^{57}$ Since 2008 , there has been a number of action and achievement in terms of the competition policy implementation. This could be seen at the table 5 below. Although the anti-dumping provisions are not stated in the AEC blueprint, it does not mean that there is kind of replacement in this matter. In fact, the anti-dumping provisions could be found in the specific agreements derive from the blueprint of AEC like ATIGA.

Cassey Lee and Yoshifumi Fukunaga, Loc.cit.

Willemien Denner, 2013, The Possible Interaction between Competition and Anti-Dumping Policy Suitable for the Southern African Customs Union (SACU), Stellenbosch University, South Africa, pp. 31-34.

${ }^{64}$ David Bienenetal., "Does Anti-Dumping Address "Unfair" Trade? The European Union's Experience", Trade and Development Discussion Paper BKP Development Research \& Consulting, No. 01, 2013, pp. 2-4.

${ }_{65}$ Robert T., 'Competition Provisions in Regional Trade Agreements' in A. Estevadeordaletal. (Ed.), 2009, Regional Rules in the Global Trading System, Cambridge University Press, UK, pp. 488-490.

66 Kasteng and Prawitz, Loc.cit.

${ }_{67}$ See ASEAN Secretariat, Loc.cit. 
Table 5. Action and Achievement of Competition Policy

\begin{tabular}{|c|c|}
\hline Proposed Actions & Achievement as at 2012 \\
\hline $\begin{array}{l}\text { Endeavour to introduce competition policy in all } \\
\text { ASEAN Member Countries by } 2015\end{array}$ & $\begin{array}{l}\text { Partial }-5 \text { AMSs have implemented } \\
\text { comprehensive national competition laws }\end{array}$ \\
\hline $\begin{array}{l}\text { Establish a network of authorities or agencies } \\
\text { responsible for competition policy to serve as a } \\
\text { forum for discussing and coordinating competition } \\
\text { policies }\end{array}$ & $\begin{array}{l}\text { Full - The ASEAN Experts Group on Competition } \\
\text { (AEGC) was established in } 2007\end{array}$ \\
\hline $\begin{array}{l}\text { Encourage capacity building programmes/activities } \\
\text { for ASEAN Member Countries in developing } \\
\text { national competition policy }\end{array}$ & $\begin{array}{l}\text { Full - Between } 2008 \text { and 2011, AEGC has } \\
\text { organized } 14 \text { capacity building activities involving } \\
700 \text { government officials from AMSs }\end{array}$ \\
\hline $\begin{array}{l}\text { iv. Develop a regional guideline on competition } \\
\text { policy by } 2010 \text {, based on country experiences and } \\
\text { international best practices with the view to creating } \\
\text { a fair competition environment }\end{array}$ & $\begin{array}{l}\text { Full - The ASEAN Regional Guideline on } \\
\text { Competition Policy was published by the ASEAN } \\
\text { Secretariat in } 2010 \text {. }\end{array}$ \\
\hline \multicolumn{2}{|l|}{ Proposed Priority Actions } \\
\hline $\begin{array}{l}\text { 2008-2009: Carrying out a foundation-laying study, } \\
\text { review of study findings and recommendations, and } \\
\text { convening a regional meeting on study findings and } \\
\text { recommendations. }\end{array}$ & $\begin{array}{l}\text { Full - The study on "Best practices in the } \\
\text { introduction and implementation of competition } \\
\text { policy and law" was completed in June } 2008\end{array}$ \\
\hline $\begin{array}{l}\text { 2010-2015: Drawing up a regional work plan on } \\
\text { Competition Policy and Law with special focus: } \\
\text { capacity building and the introduction of best } \\
\text { practices for introducing competition policy. }\end{array}$ & $\begin{array}{l}\text { Full - AEGC tabled a capacity building roadmap } \\
\text { at the Sixth AEGC Meeting in July } 2010\end{array}$ \\
\hline $\begin{array}{l}\text { 2010-2015: Exploring funding opportunities for the } \\
\text { implementation of selected elements of the work } \\
\text { plan in line with the strategic schedules of AEC } \\
\text { building. }\end{array}$ & $\begin{array}{l}\text { Full - AEGC received funding for capacity } \\
\text { building from InWEnt }(2009-2010,2011-2013) \\
\text { and ASEAN-GIZ (2011-2014) }\end{array}$ \\
\hline
\end{tabular}

Source: ASEAN Secretariat, ASEAN Regional Guidelines on Competition Policy, 2010.

Accordingly, it obviously can be said that both anti-dumping provisions and competition policy have been adopted in AEC regulations. In that sense, although the replacement of anti-dumping has occurred in some regional trade arrangements, the framework of AEC does not allow the competition policy to replace the antidumping actions.

\section{Conclusion}

As the conclusion, it could be said that the free flow of goods in AEC generally might bring effect in the use of Indonesia anti-dumping actions. Its effect could be whether increase or reduce the practice of anti-dumping measures. The possible effect in the intensification of the anti-dumping tends to be done in order to protect domestic industry in Indonesia. On the other hand, the free flow of goods in AEC is likely to reduce the use of anti-dumping actions in Indonesia. This is because the lack of law enforcement, corruption and the lack of anti-dumping enforcers.

Although there are some regional trade agreements that have removed the use of antidumping measures, there is no a possible chance for Indonesia neither other ASEAN member states to eliminate the trade remedies provision specifically in anti-dumping measures. This is because AEC through free flows of goods scheme under the ATIGA (ASEAN Trade in Goods Agreement) has included the trade remedies provisions. As a result, the anti-dumping measures would not be replaced with competition policy due to the existence of both provisions in the blueprint of AEC. 


\section{REFERENCES}

\section{A. Books}

ASEAN Secretariat, 2008, ASEAN Economic Community Blueprint, ASEAN Secretariat, Jakarta.

Bossche, Peter Van den, 2008, The Law and Policy of the World Trade Organization: Text, Cases and Materials, 2nd Ed, Cambridge University Press, New York.

Czako, J., et al. (Ed.), 2003, World Trade Organization: A Handbook on Anti-Dumping Investigations, Cambridge University Press, U.K.

Denner, Willemien, 2013, The Possible Interaction between Competition and Anti-Dumping Policy Suitable for the Southern African Customs Union ( $S A C U$ ), Stellenbosch University, South Africa.

Makkawaru, Imam Kharisma, 2012, Implementation of Anti-Dumping Law in Indonesia as Trade Remedies in the Frame of International Law, Thesis, University of Indonesia, Jakarta.

The Economic Research Institute for ASEAN and East Asia (ERIA), 2012, Mid-Term Review of the Implementation of the AEC Blueprint Executive Summary, The Economic Research Institute for ASEAN and East Asia (ERIA), Jakarta.

Widayanto, Sulistyo, 2007, Negosiasi untuk Mengamankan Kepentingan Nasional di Bidang Perdagangan, Ditjen KPI, Jakarta.

World Trade Report, 2011, The WTO and Preferential Trade Agreements: From Coexistence to Coherence, World Trade Organization, Geneva.

\section{B. Article of Journal}

Bhagwati, J., and A. Panagariya, "Preferential Trading Areas and Multilateralism: Strangers, Friends or Foes?", Discussion Paper Series Department of Economics Columbia University, No. 9596-04, 1996.

Bienenetal, David, "Does Anti-Dumping Address "Unfair" Trade? The European Union's
Experience", Trade and Development Discussion Paper BKP Development Research \& Consulting, No. 01, 2013.

Blonigen, Bruce A., and Thomas J. Prusa, "Antidumping", Working Paper, National Bureau of Economic Research, 2001.

Cassey Lee and Yoshifumi Fukunaga, "Competition Policy Challenges of Single Market and Production Base", Discussion Paper Series ERIA, No. 17, 2013.

Chia, Siow Yue, "The ASEAN Economic Community: Progress, Challenges and Prospects", ADBI Working Paper Series Asian Development Bank Institute, No. 440, 2013.

Cuyvers, Ludo, et al., "From AFTA towards an ASEAN Economic Community And Beyond", CAS Discussion Paper Central for ASEAN Studies, No. 46, January 2005.

Farha, Ryan, "A Right Unexercised is A Right Lost? Abolishing Anti-Dumping in Regional Trade Agreements", Georgetown Journal of International Law, No. 44, 2012.

Feinberg, Robert M., “Anti-Dumping As Development Issue", Global Economy Journal, Vol. 11, No. 3, 2011.

Gumilang, Howard, et al., "Economic and Environmental Impacts of Trade Liberalization: The Case of Indonesia”, Economic Modeling, No. 28, 2011.

Hartigan, James C., and Hylke Vandenbussche, "Why Does the WTO have an Anti-Dumping Agreement?", Discussion Papers LICOS Centre for Institutions and Economic Performance, No. 253, 2010.

Hew, Denis, "Economic Integration in East Asia: An ASEAN Perspective", UNISCI Discussion Paper Institute of Southeast Asian Studies, No. 11, May 2006.

Kirchner, Stephen, “Time to Dump Australia's AntiDumping System”, Issue Analysis The Centre for Independent Studies, No. 141, 2013.

Kasteng, Jonas, and Camilla Prawitz, "Effects on 
Trade and Competition of abolishing AntiDumping Measures: The European Union Experience", Kommerskollegium National Board of Trade, No. 6, 2013. and Camilla Prawitz, "Eliminating Anti-Dumping Measures in Regional Trade Agreements", Kommerskollegium National Board of Trade, No. 5, 2013.

Losari, Junianto James, and Joseph Wira Koesnaidi, "Indonesia and the Establishment of the ASEAN Economic Community in 2015: Are We There Yet?", Policy Brief Asian Development Bank, No. 10, 2014.

Martin, Alberto, and Wouter Vergote, "On the Role of Retaliation in Trade Agreements", Journal of International Economics, No. 76, 2008.

Prusa, Thomas J., "Anti-Dumping: A Growing Problem in International Trade", The World Economy, Vol. 28, No. 5, 2005.

Prusa, Thomas J., and Robert Teh, "Protection Reduction and Diversion: PTAs and the Incidence of Anti-Dumping Disputes", Working Paper National Bureau of Economic Research, No. 16276, 2010.

Teh, Robert, et al., "Trade Remedy Provisions in Regional Trade Agreements", Staff Working Paper ERSD, No. 3, 2007.

Tharakan, P.K.M., "Political Economy and Contingent Protection", The Economic Journal, 105, 433, 1995.

Rey, J.D., "Anti-Dumping Regional Regimes and the Multilateral Trading System: Regional Antidumping Regimes Do Make a Difference?", Staff Working Paper ERSD, No. 22, 2012.

Schoenbaum, Thomas J., "Antidumping and Countervailing Duties and the GATT: An Evaluation and Proposal for a Unified Remedy for Unfair International Trade", German Y.B.I.L, 30, 1987.

Wei, Dan, "Antidumping in Emerging Countries in the Post-crisis Era: A Case Study on Brazil and China", Journal of International Economic Law, No. 16, 2013.

\section{Paper}

Charumanee, Kuboon, "ASEAN Economic Community (AEC) 2015 and Its Implication on APEC", Paper, The Annual Conference for the APEC Study Center Consortium, Kazan, Russia, 26-27 May 2012.

Tin, Ooi Guat, "The Preferential Trading Arrangements (PTA): An Analysis of Potential Effects on Intra-ASEAN Trade", Research Note and Discussion Paper, ASEAN Economic Research Unit, Institute of Southeast Asian Studies, No. 26, Singapore, 1981.

\section{Anthology}

Austria, M. S., "Non-Tariff Barriers: A Challenge to Achieving the ASEAN Economic Community", in S.B. Das et al. (Ed.), 2013, the ASEAN Economic Community: A Working in Progress, Institute of Southeast Asian Studies, Singapore.

Petri, P. A., "Asia and the World Economy in 2030: Growth, Integration, and Governance," in A. J. Tellis et al. (Eds.), 2010, Strategic Asia: Asia's Rising Power and America's Continued Purpose, The National Bureau of Asian Research, Seattle.

Ravenhill, J., "Regional Trade Agreements", in J. Ravenhill (Ed.), 2011, Global Political Economy, Oxford University Press, London.

Robert T., "Competition Provisions in Regional Trade Agreements", in A. Estevadeordaletal. (Ed.), 2009, Regional Rules in the Global Trading System, Cambridge University Press, UK.

Urata, S., and M. Okabe, "Tracing the Progress Toward the ASEAN Economic Community: Overview Chapter 1", in S. Urata and M. Okabe (Ed.), "Tracing the Progress Toward the ASEAN Economic Community", Research Project Report 2009 Economic Research Institute for ASEAN and East Asia, No. 3, 2010. 


\section{E. Internet Sources}

ASEAN, "Declaration on the ASEAN Economic Community Blueprint", http://www.asean. org/news/item/declaration-on-the-aseaneconomic-community-blueprint, accessed on 13 February 2014.

ASEAN, "Agreement on the ASEAN Preferential Trading Arrangements", http:// agreement.asean.org/media/download/ 20140119163517.pdf, accessed on 13 February 2014.

Association of Southeast Asian Nations, "Non-tariff Barrier", http://www.asean.org/communities/ asean-economic-community/item/non-tariffbarriers, accessed on 13 February 2014.

Hansakul, Syetarn, “ASEAN Economic Community (AEC) A Potential Game Changer for ASEAN Countries", https://www.dbresearch. com/PROD/DBR_INTERNET_EN-PROD/ PROD0000000000315342/ASEAN+Econom $i c+$ Community $+(A E C) \% 3 A+A+$ potential $+g$ ame + changer + for + ASEAN + countries.pdf., accessed on 14 February 2015.

Runckel, Christopher W., "Asia Opportunities: ASEAN Economic Community (AEC) in 2015", http://www.business-in-asia.com/ asialasean_economic_community.html, accessed on 24 February 2014.

Wittayarungruangsri, Sarut, "Antidumping: A Villain in International Trade", http:// economics.about.com/cs/moffattentries/a/ antidumping.htm, accessesd on 23 February 2014.

WTO Statistic on Anti-Dumping, 2013, "AntiDumping Measures by Reporting Member 01/01/1995-30/06/2013", ～http://www. wto.org/english/tratop_eladp_e/AD_ MeasuresByRepMem.pdf, accessed on 15 February 2014.

WTO Statistic on Anti-Dumping, 2013, "AntiDumping Initiations: Reporting Member vs Exporting Country 01/01/1995-30/06/2013”, http://wto.org/english/tratop_eladp_e/AD_ InitiationsRepMemVsExpCty.pdf., accessed on 15 February 2014.

\section{F. Convention}

Agreement on Implementation of Article VI of the General Agreement on Tariffs and Trade 1994, open for signature 15 April 1994, 1868 UNTS 201 (entered into force 01 January 1995) Article 1.

ASEAN Trade in Goods Agreement, opened for signature 26 February 2009 (entered into force 17 Mei 2010) Article 86.

Marrakesh Agreement Establishing the World Trade Organization, opened for signature 15 April 1994, 1867 UNTS 187 (entered into force 1 January 1995) annex 1A ('GATT 1994') Article 6. 